\title{
Bioremediation of nitrate-polluted groundwater in a microbial fuel cell
}

N. Pous, S. Puig ${ }^{*}$, M. Coma, M.D. Balaguer, and J. Colprim

Laboratory of Chemical and Environmental Engineering (LEQUiA), Institute of the

Environment, University of Girona, C/ Maria Aurèlia Capmany, 69, Facultat de Ciències, E17071 Girona, Spain.

* Corresponding author:

E-mail address: sebastia@lequia.udg.cat (S. Puig)

Tel: +34972418182 ; Fax: +34972418150

This article has been accepted for publication and undergone full peer review but has not been through the copyediting, typesetting, pagination and proofreading process, which may lead to differences between this version and the Version of Record. Please cite this article as doi: $10.1002 / \mathrm{jctb} .04020$ 


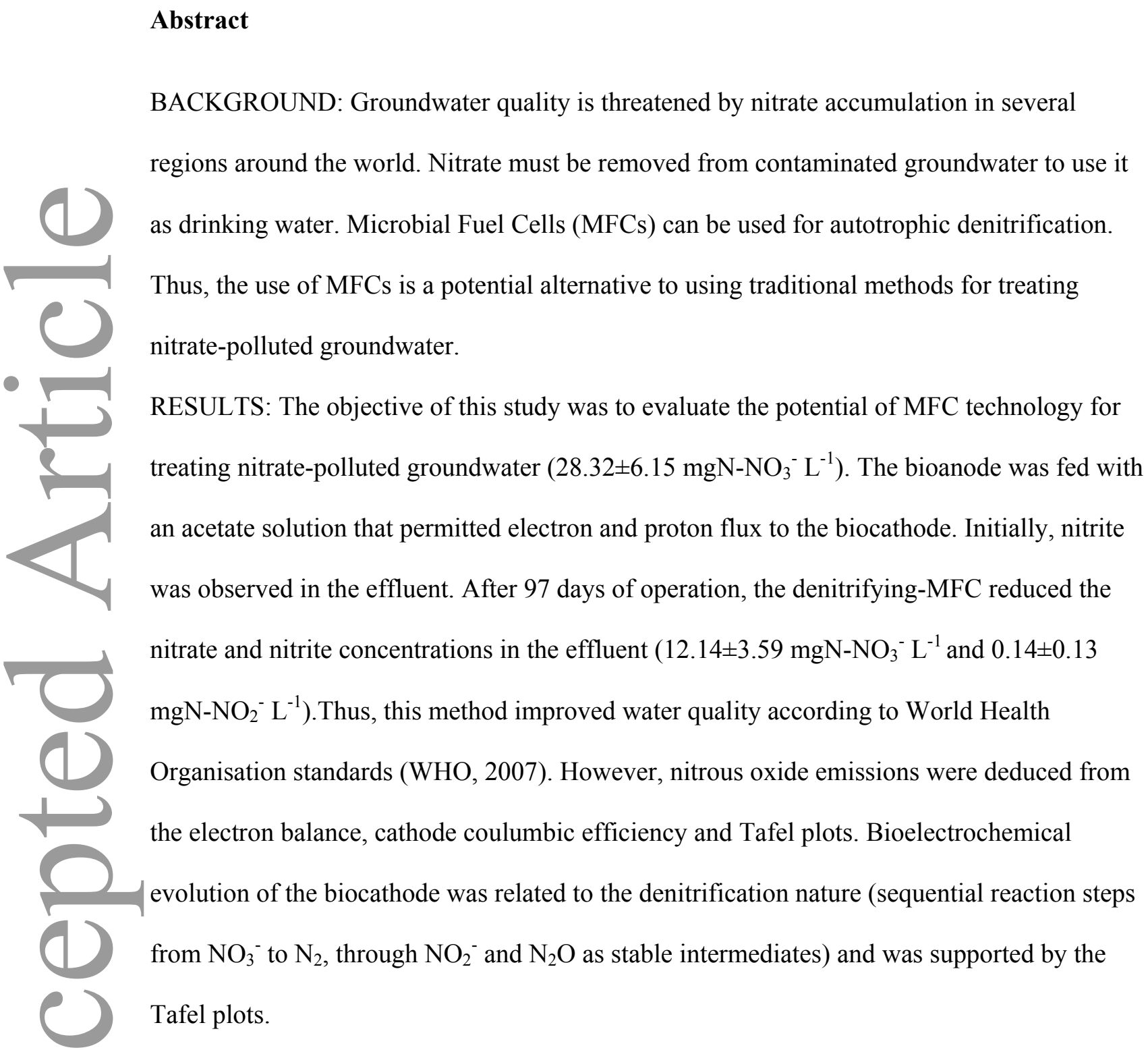

CONCLUSION: The bioremediation of nitrate-polluted groundwater with a MFC biocathode is feasible.

\section{Keywords:}

Biocathode; bioelectrochemical systems; biological autotrophic denitrification; drinking water. 


\section{INTRODUCTION}

Intensive agriculture and livestock production and other non-point sources have led to nitrate pollution in aquifers around the world. ${ }^{1,2}$ Because the majority of the world's population relies on groundwater as a drinking water source, nitrate-contaminated groundwater has become a major problem. Thus, due to nitrate poising in the United States, the Safe Drinking Water Act, which was passed in 1976, includes nitrate regulations and special protection for aquifers. ${ }^{3}$ In subsequent amendments, a protection program for public wells was implemented. In Europe, the Nitrates Directive, the Water Framework Directive, and the Groundwater Directive address nitrate pollution of groundwater. These directives require nitrate monitoring and reduction. ${ }^{4-6}$

Different technologies can be used to remove nitrates from groundwater to obtain drinking water. Currently, the Environmental Protection Agency (EPA) considers only ion exchange, reverse osmosis and reverse electrodialysisas effective methods for decreasing nitrate concentration to below their drinking water limits. ${ }^{7}$ These technologies yield high-quality drinking water. However, these technologies also have some drawbacks, including energy requirements and the generation of waste brine (nitrate is separated from groundwater, not treated), which requires additional treatment. ${ }^{8}$

Microbial Fuel Cells (MFCs) could be considered as an alternative to these separation technologies. Nitrate removal by MFCs has been studied recently for wastewater treatment. ${ }^{9,10}$ Intermediate denitrification species, such as nitrites $\left(\mathrm{NO}_{2}^{-}\right)$and nitrous oxide $\left(\mathrm{N}_{2} \mathrm{O}\right)$, have also been considered. ${ }^{11,12}$ Following the removal of these intermediate species, nitrate reduction to dinitrogen gas can occur in the MFC biocathode.

Recent studies have stated that low conductivities promote the accumulation of denitrification intermediates (such as nitrite and nitrous oxide), reduce cell potentials and 
decrease nitrogen removal. ${ }^{13}$ Thus, MFCs have been applied to treat nitrates and nitrites in wastewater with high conductivities (2000- $\left.11000 \mu \mathrm{S} \mathrm{cm}^{-1}\right)$. However, to our knowledge, MFCs have never been used to treat nitrates in waters with low -conductivity, such as groundwater $\left(<1000 \mu \mathrm{S} \mathrm{cm}^{-1}\right)$.

Due to the peculiarities of groundwater and MFCs, different challenges must be overcome to obtain drinking water from nitrate-polluted groundwater. These challenges include the following: i) groundwater contains no organic matter and nitrates should be treated by autotrophic denitrification, and ii) conductivity affects the performance of MFCs, which implies that nitrate treatment is less efficient in waters with low-ionic-strengths, such as groundwater. $^{13}$

Thus, groundwater that contains unhealthy levels of nitrates was used to feed a MFC biocathode to reduce the nitrate concentrations. Polarization curves were generated regularly by Tafel plot analysis to understand the bioelectrochemistry involved in denitrification. Finally, the biofilm growth in the anode and cathode was observed. Other parameters of water quality ( $\mathrm{pH}$, conductivity, sulphates, chlorides, turbidity and organic matter (total organic carbon (TOC)) were monitored to determine if the bioremediation process impacted them.

\section{EXPERIMENTAL}

\subsection{Experimental set-up}

The MFC consisted of an anode and a cathode placed on opposite sides of a single rectangular methacrylate chamber. The anode and cathode chambers were filled with granular graphite (model 00514, diameter 1.5-5 mm, EnViro-cell, Germany), which decreased the net anodic and cathodic compartment volumes to 450 and $600 \mathrm{~mL}$ net (NAC and $\mathrm{NCC}$ ), respectively. Two thinner graphite electrodes (107 x $6 \mathrm{~mm}$ (anode) and $130 \times 6 \mathrm{~mm}$ (cathode), Sofacel, Spain) were connected to the external resistor (25 $\Omega$ ) to close the electric 
circuit. A cation exchange membrane (CEM, Nafion ${ }^{\circledR} 117$, DuPont, USA) was placed between the anode and cathode frames. Water was continuously fed at a steady state flow rate of 1.23 and $1.21 \mathrm{~L} \mathrm{~d}^{-1}$ in the anodic and cathodic compartments, respectively. An internal recirculation loop $\left(105 \mathrm{~L} \mathrm{~d}^{-1}\right)$ was placed in each compartment. The system was controlled with a thermostat at $22 \pm 1^{\circ} \mathrm{C}$.

\subsection{Influent characteristics}

Nitrogen-purged groundwater from the village of Navata (Girona, N.E. Spain) was fed into the cathode compartment. The characteristics of this groundwater are shown in Table 1. During the entire study period, the groundwater contained $28.32 \pm 6.15 \mathrm{mg} \mathrm{N}^{-\mathrm{NO}_{3}}{ }^{-} \mathrm{L}^{-1}$ and $0.24 \pm 0.40 \mathrm{mg} \mathrm{N}-\mathrm{NO}_{2}{ }^{-} \mathrm{L}^{-1}$ (the limits given by Spanish legislation are $11.29 \mathrm{mg} \mathrm{N}-\mathrm{NO}_{3}{ }^{-} \mathrm{L}^{-1}$ $\left(50 \mathrm{mg} \mathrm{NO}_{3}{ }^{-} \mathrm{L}^{-1}\right)$ and $0.91{\mathrm{mg} \mathrm{N}-\mathrm{NO}_{2}}^{-} \mathrm{L}^{-1}\left(3 \mathrm{mg} \mathrm{NO}_{2}{ }^{-} \mathrm{L}^{-1}\right)) .{ }^{14}$ Furthermore, the mean value for inorganic carbon was $59.6 \pm 3.8 \mathrm{mg} \mathrm{C} \mathrm{L}^{-1}$ And the average $\mathrm{pH}$ was $8.0 \pm 0.2$. In addition, this water had a low conductivity relative to that of the water used in previous studies $(955 \pm$ $121 \mu \mathrm{S} \mathrm{cm}^{-1}$ ). No ammonium $\left(\mathrm{N}^{-\mathrm{NH}_{4}}{ }^{+}\right.$) or organic matter (analysed as Total Organic Carbon (TOC)) was detected.

The anode was fed with acetate-enriched water (based on Puig ${ }^{13}$ ) with a chemical oxygen demand (COD) concentration of $283 \pm 75 \mathrm{mg} \mathrm{COD} \mathrm{L}^{-1}$, a pH of $7.6 \pm 0.1$ and a low conductivity of $1089 \pm 158 \mu \mathrm{S} \mathrm{cm}^{-1}$. To avoid substrate limitations, anodic influent had higher COD concentrations than required stoichiometric concentration for nitrate removal.

\subsection{MFC operation}

The MFC was inoculated with the effluent from a parent MFC to treat acetate (anode) and nitrite (cathode) -enriched wastewaters with high conductivities $\left(3754 \pm 1014 \mu \mathrm{S} \mathrm{cm}^{-1}\right) .{ }^{11} \mathrm{~A}$ 
denitrification rate of $75.7 \pm 12.4 \mathrm{~g} \mathrm{~N} \mathrm{~m}^{-3} \mathrm{~d}^{-1}$ was achieved in this reactor. The MFC operation was studied for a period of 97 days. The conductivity of the anode was fixed to match the conductivity of the groundwater that was used as the cathodic influent. To simplify data interpretation, the data from the entire process were divided into five periods with at least four samples per period. The results from these different periods were expressed as the mean and standard deviation of the measurements. Polarization curve analysis was performed to electrochemically characterise the MFC.

\subsection{Analyses and calculations}

Standard wastewater measurements were taken regularly for organic matter ((COD), (TOC)), nitrogen (nitrites $\left(\mathrm{N}-\mathrm{NO}_{2}{ }^{-}\right)$, nitrates $\left({\mathrm{N}-\mathrm{NO}_{3}}^{-}\right)$, ammonium $\left(\mathrm{N}-\mathrm{NH}_{4}{ }^{+}\right)$), sulphates $\left(\mathrm{S}^{-} \mathrm{SO}_{4}{ }^{2-}\right)$, chlorides $\left(\mathrm{Cl}^{-}\right)$and phosphates $\left(\mathrm{P}-\mathrm{PO}_{4}{ }^{3-}\right)$. These analyses were conducted according to the recommendations of the American Public Health Association (APHA). ${ }^{15}$ The $\mathrm{pH}$, conductivity and turbidity (Turbidimeter TN-100, Eutech instruments) of the influent and effluent of the anodic and cathodic chambers were regularly measured.

The nitrous oxide production levels were calculated from the electron balance at the cathode by using the methodology proposed by Virdis. ${ }^{16}$ The nitric oxide (NO) production was considered to be negligible. To achieve mass balance, the concentration of dinitrogen gas in the effluent was calculated.

The cell potential (V) in the MFC circuit was monitored at one-minute intervals with an on-line multimeter (Alpha-P, Ditel, Spain) that contained a data acquisition system $\left(\right.$ Memograph $^{\circledR}$ M RSG40, Endress + Hauser, Germany). The current (I) and power (P=IV) were determined by using Ohm's law. The power and current densities were calculated by dividing the power or current by the net cathodic volume. The anodic and cathodic coulombic efficiencies (CE) were computed according to Virdis. ${ }^{10}$ 
The cathode and anode potentials were monitored with an $\mathrm{Ag} / \mathrm{AgCl}$ reference electrode (0.197 V vs the Standard Hydrogen Electrode (SHE), model RE-5B BASi, United Kingdom). Polarization curve analyses were performed once per week with a potentiostat (model SP50, Bio-logic, France) that imposed a linear potential decrease of $1 \mathrm{mV} \mathrm{s}^{-1}$ from the open circuit voltage $(\mathrm{OCV})$ to a cell voltage of $0 \mathrm{mV}$ before imposing a linear cell voltage increase of 1 $\mathrm{mV} \mathrm{s}^{-1}$ to the original OCV. Before inoculating the MFC, a polarization curve was conducted. In this polarization curve, the MFC was fed with the same influents that were used in the study (acetate-enriched water at the anode and nitrate-polluted groundwater at the cathode). The results obtained from the polarization curve without microorganisms were used as an abiotic control.

To analyse the polarization curve results, the Tafel equation was applied. The Tafel equations that were used for the oxidative and reductive current are shown in equations 1 and 2 , respectively. ${ }^{17}$

$$
\begin{aligned}
& \ln i=\ln i_{0}+((\beta n F \eta) /(R T)) \\
& \ln i=\ln i_{0}-((\alpha \cap F \eta) /(R T))
\end{aligned}
$$

Where $i_{0}$ is the exchange current density, $i$ is the electrode current density $\left(\mathrm{A} \mathrm{m}^{-3} \mathrm{Net}\right.$ chamber), $F$ is the Faraday constant $\left(96485 \mathrm{C} \mathrm{mol}^{-1} \mathrm{e}^{-}\right), R$ is the ideal gas constant $(8.31 \mathrm{~J}$ $\left.\mathrm{mol}^{-1} \mathrm{~K}^{-1}\right), T$ is the absolute temperature $(\mathrm{K}), n$ is the number of electrons involved in the rate determining step, $\eta$ is the overpotential, which is the shift of electrode potential (E) and the equilibrium potential $\left(\mathrm{E}^{0}\right)$, and $\beta$ and $\alpha$ are anodic and cathodic transfer coefficients, respectively. In addition, $\beta$ and $\alpha$ indicate the oxidative kinetic activity and the reductive kinetic activity, respectively. The Tafel equation was fit at large overpotentials, where $\mid((F$ $\eta) /(R T)) \mid>1 .^{18}$ 


\subsection{Biofilm morphology determination}

Scanning Electron Microscope (SEM) analyses were performed. Graphite samples from the anodic and cathodic chambers and treated graphite (as a control) were analysed to compare the biofilms. The samples were immersed in $2.5 \%(\mathrm{w} / \mathrm{v})$ glutaraldehyde in a $0.1 \mathrm{M}$ cacodylate buffer at $\mathrm{pH}$ 7.4. Next, the samples were washed and dehydrated in an ethanol series. The fixed samples were dried with a critical-point drier and sputtered-coated with a $40 \mathrm{~nm}$ gold layer. The coated samples were examined with a SEM (model DSM-960; Zeiss, Germany) at $20 \mathrm{kV}$, and the images were captured digitally.

\section{RESULTS AND DISCUSSION}

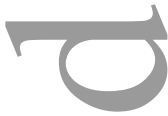

\subsection{Reduction of nitrate in polluted groundwater in a biocathode MFC}

Data obtained during the entire process (97 days) were divided into five periods to simplify the interpretation. Figure 1 shows the mean influent and effluent nitrate concentrations and the effluent nitrite concentrations during the experimental period. The nitrous oxide and dinitrogen gas concentrations in the effluent were calculated from the electron balance. These results are also shown in Figure 1.

Despite the use of biomass that was not acclimated to low conductivities (around $1000 \mu \mathrm{S}$ $\mathrm{cm}^{-1}$ ), nitrate removal was observed from the first few days of operation. The nitrate concentration at the end of the experimental period was $12.14 \pm 3.59 \mathrm{mg} \mathrm{N}-\mathrm{NO}_{3}{ }^{-} \mathrm{L}^{-1}$ (removal efficiency of 64\%). However, the production of nitrite, an intermediate of nitrate reduction, was detected during the first 45 days. During this time frame, the nitrite production increased from $4.32 \pm 2.34 \mathrm{mg} \mathrm{N}-\mathrm{NO}_{2}{ }^{-} \mathrm{L}^{-1}$ (0-15 d) to $7.20 \pm 3.99 \mathrm{mg} \mathrm{N}-\mathrm{NO}_{2}{ }^{-} \mathrm{L}^{-1}$ (31-45 d). 
After the initial 45 days of the study period, the nitrite production decreased before reaching $0.14 \pm 0.13 \mathrm{mg} \mathrm{N}-\mathrm{NO}_{2}{ }^{-}$at 84 to $97 \mathrm{~d}$.The nitrogen removal rate (calculated as removal of nitrates and nitrites)increased from $17.00 \pm 3.94 \mathrm{gN} \mathrm{m}^{-3} \mathrm{NCC} \mathrm{d}^{-1}$ in the first period to $47.56 \pm 2.44 \mathrm{gN} \mathrm{m}^{-3} \mathrm{NCC} \mathrm{d}^{-1}$ in the last period. Throughout the study, a maximum nitrogen removal rate of $51.37 \mathrm{gN} \mathrm{m}^{-3} \mathrm{NCC} \mathrm{d}^{-1}$ was obtained.

Nitrite accumulation indicated that the nitrate was not completely reduced. Because nitrate reduction to dinitrogen gas is governed by a sequence of reduction steps that involve several intermediate species $\left(\mathrm{NO}_{2}^{-}, \mathrm{NO}\right.$ and $\left.\mathrm{N}_{2} \mathrm{O}\right)$, nitrite accumulation may indicate that the nitrite reduction step did not occur as expected. Thus, the decrease in nitrite accumulation after a certain time could result from acclimation, which is similar to the initial behaviour of the conventional denitrification processes. However, because biomass used to inoculate the biocathode, successfully treated nitrite enriched wastewater ${ }^{11}$, the observed high nitrite accumulation was surprising. Both systems had different influent characteristics, which consisted of synthetic nitrite-enriched wastewater with high conductivity $(3754 \pm 1014 \mu \mathrm{S}$ $\left.\mathrm{cm}^{-1}\right)$ and nitrate-polluted groundwater with low conductivity $\left(955 \pm 121 \mu \mathrm{S} \mathrm{cm}^{-1}\right)$. These differences may lead to the conclusion that changing influent characteristics affect the microbial community.

During the periods when nitrite accumulated in the system (until day 45), the cathodic coulumbic efficiency was approximately $80 \%$. However, as nitrite was successfully removed (periods after day 45), the cathodic coulumbic efficiency was reduced to approximately $60 \%$. This decrease could indicate the occurrence of intermediate accumulation. ${ }^{16}$ In the reduction sequence of nitrate to dinitrogen gas, only nitrite and nitrous oxide are stable enough to accumulate. Because nitrite analyses were performed and accounted for in the cathode coulumbic efficiency calculations, the lower cathode coulumbic efficiencies were interpreted as nitrous oxide accumulation. Unfortunately, $\mathrm{N}_{2} \mathrm{O}$ analyses could not be performed at that 
time. However, experiments carried out using liquid- and gas- phase $\mathrm{N}_{2} \mathrm{O}$ analyses demonstrated excellent fits between measured and estimated data using the electron balance (data not shown). Thus, the electron balance was used to estimate the nitrous oxide production at the biocathode. Electron balance cannot provide the exact $\mathrm{N}_{2} \mathrm{O}$ production because it considers that all current is produced from nitrate reduction. However, other reduction reactions can also produce certain currents. In addition, because no changes were made during the MFC operation of this study, the other reduction reactions would have remained nearly constant. Consequently, the electron balance cannot be used to determine the exact $\mathrm{N}_{2} \mathrm{O}$ concentration. However, the electron balance can tell if a large change in $\mathrm{N}_{2} \mathrm{O}$ concentration occurs. Thus, the electron balance was used in this study to estimate $\mathrm{N}_{2} \mathrm{O}$ accumulation. These data showed that nitrite depletion was followed by increasing nitrous oxide production. As previously observed, nitrous oxide accumulation indicated slower bacterial $\mathrm{N}_{2} \mathrm{O}$ reduction activity than in previous reactions $\left(\mathrm{NO}_{2}{ }^{-}\right.$reduction). When nitrite reducing bacteria populations grew, nitrite accumulation began to decrease. Thus, it is expected that nitrous oxide -reducing bacteria can grow. ${ }^{12}$ The low conductivities that are associated with groundwater characteristics must be considered. Higher autotrophic nitrogen removal efficiencies occurred in the MFC biocathode as the conductivity increased. ${ }^{13}$ However, when the bacteria have had enough time to acclimate, the nitrate and nitrite concentrations can be reduced despite the low conductivity of the groundwater. Besides the accumulation of nitrous oxide, according to drinking water quality standards, ${ }^{14,19}$ reducing nitrate and nitrite contents should be a primary goal for treating groundwater polluted with nitrate. 
3.2 Electron donor requirements for nitrate reduction

The anode of the MFC was fed with enriched acetate water with average organic matter concentration and conductivity values of $283 \pm 75 \mathrm{mg} \mathrm{COD} \mathrm{L}^{-1}$ and $1089 \pm 158 \mu \mathrm{S} \mathrm{cm}^{-1}$, respectively.

Before day 45, anodic microorganisms were unable to oxidise all of the organic matter that was fed into the reactor ( $50 \%$ organic matter removal efficiencies were achieved). However, after day 45 , the organic matter removal efficiency began to increase to approximately $90 \%$.

During the entire study, the anodic coulombic efficiencies were maintained at low values of approximately $11 \pm 2$ and $15 \pm 4 \%$. The small observed coulombic efficiencies at the anode indicated that acetate consumption occurred by non-exoeletrogenic bacteria. The faster growth of the non-exoeletrogenic bacteria indicated that the overpotentials limited electroactive activity. ${ }^{13,20}$

\subsection{Bioelectrochemical kinetic activity}

Polarization curves were regularly generated to understand the electrochemistry that was involved in the evolution of nitrogen removal in the MFC. Tafel plots were applied for the cathodic and anodic chamber from the polarization curve results. These results are shown in Figure 2 .

Table 2 shows the results obtained from the Tafel plot analysis at the anode and the cathode, including the alpha $(\alpha)$, beta $(\beta)$, exchange current density $\left(i_{0}\right)$ and the equilibrium potential $\left(\mathrm{E}^{0}\right)$. 
First, the results of the cathode were considered in terms of equilibrium potential, for which two different periods were distinguished. Until day 45 , the equilibrium potential was maintained at values below $-40 \mathrm{mV}$ vs. SHE. However, between day 56 and day 89, the equilibrium potential increased to values of approximately $+50 \mathrm{mV} v s$. SHE. Considering the standard cathodic potentials of the series of reactions that are involved in nitrate reduction to nitrogen gas, ${ }^{9}$ an increase in the cathodic equilibrium potential in a denitrifying biocathode can be interpreted as a decrease in the cathode overpotential. This change in cathodic potential was followed by an increase in the nitrate and nitrite removal capacities. Before day 56 , when the equilibrium cathodic potential was around $-40 \mathrm{mV}$ vs. SHE, the mean nitrogen removal rate (expressed as nitrite and nitrate removal) was $19.72 \pm 5.57 \mathrm{gN} \mathrm{m}^{-3} \mathrm{NCC} \mathrm{d}^{-1}$. Between day 56 and 89 , when the equilibrium cathodic potential rose to $+50 \mathrm{mV}$ vs. SHE, the mean nitrogen removal rate increased to $42.32 \pm 6.42 \mathrm{gN} \mathrm{m}^{-3} \mathrm{NCC} \mathrm{d}^{-1}$. The reduction of the cathode overpotential and the increase in removal capacity were combined to indicate the development of more active bacteria, which are more efficient at transferring electrons from the cathode to the final electron acceptor (nitrate or nitrite).

The $\alpha$ and $i_{0}$ values were calculated from the cathodic chamber. From 15 to 45 days, the exchange current density values were between 3.15 and $8.00 \mathrm{~A} \mathrm{~m}^{-3} \mathrm{NCC}$. However, the polarization curve on day 68 reached the highest value of $9.11 \mathrm{~A} \mathrm{~m}^{-3} \mathrm{NCC}$. The greater activity on day 68 corresponded with greater nitrate and nitrite removal efficiency.

For the same electrochemical reaction, $\alpha$ values provide essential information for comparing its kinetic behavior. The lower the $\alpha$ values (lower Tafel slope), the higher the kinetic activity. ${ }^{21}$ However, when more than one reaction can take place in the same electrode, $\alpha$ data interpretation becomes more complex. In section 3.1 it was demonstrated that the biocathodic reactions changed during the study. Prior to day 45, the MFC was characterised by high nitrite accumulation, which indicated that nitrite reduction was the 
slowest reaction (the rate determining step reaction). However, although nitrate reduction was faster than nitrite reduction, nitrate was not completely reduced. Thus, during those days, the cathodic $\alpha$ values represents a mixture of nitrate and nitrite reduction. During the initial 45 days, the $\alpha$ was between 0.23 (day 15) and 0.18 (day 45), which indicated that few differences beyond an increase in kinetic activity occurred. During these days nitrate and nitrite removal increased from 12.51 to $19.04 \mathrm{gN} \mathrm{m}^{-3} \mathrm{NCC} \mathrm{d}^{-1}$ (day 27).

After day 45, decreasing levels of nitrite accumulation were observed until none occurred. However, nitrous oxide increased according to the electron balance. Furthermore, $\alpha$ reached its lowest value (0.18) at day 45 . The lowest $\alpha$ value indicated that the highest kinetic activity of the reactions that were predominantly taking place (nitrate and nitrite reduction) occurs. This result supports the finding that bacteria are able to reduce nitrates and nitrites once they become acclimated and begin working more efficiently.

Polarization curves on days 56, 68 and 89 had higher cathode $\alpha$ values (higher Tafel slopes) than previous days, which potentially indicates lower kinetic activity in the biocathode. However, on days 56, 68 and 89 experimental results that were based on nitrate and nitrite reduction indicated higher kinetic activity because higher concentrations of nitrate and nitrite were removed. Thus, the changes of the Tafel slope potentially indicate that the rate-limiting step reaction has changed. In addition, this decreasing kinetic activity corresponded with days where lower cathodic coulumbic efficiencies were observed (it decreased from 80 to $60 \%$ ). This result is consistent with the electron balance results that indicated higher nitrous oxide accumulation during the final days of the study. The transition from nitrite to nitrous oxide agglomeration implies that the slowest reaction (rate-determining step reaction) transitioned from $\mathrm{NO}_{2}{ }^{-}$reduction to $\mathrm{N}_{2} \mathrm{O}$ reduction. 
Regarding the results obtained from the anode, the anodic chamber performance was characterised by low columbic efficiencies (between 10-15\%) despite the increased total carbon removal during the study. Considering the Tafel analysis results, the $\beta$ values (reference data value for an electrode working as an anode) decreased from 0.28 (day 15) to 0.17 (day 89), which indicated increasing anode kinetic activity.

Finally, the exchange current density $\left(i_{0}\right)$ that was observed for the anode (values between $5.25-8.73 \mathrm{~A} \mathrm{~m}^{-3}$ ) was usually higher than the cathodic exchange current density (values between $3.15-9.11 \mathrm{~A} \mathrm{~m}^{-3}$ ). This result indicated that the overall anode kinetic activity was usually higher than the cathodic activity. Thus, the MFC performance was highly limited by the cathodic reaction. The cathodic limitation allowed non-exoelectrogenic bacteria to grow in the anodic chamber, which reduced its coulumbic efficiency.

\subsection{Anodic and cathodic biofilms: two different worlds}

To evaluate the biofilm evolution of each chamber, graphite samples were taken from the anodic and cathodic chambers. These samples were visualised by using a scanning electron microscopy (SEM) on day 78. These images were compared with the SEM images of treated graphite (used as a control). Figure S1 contains the SEM images of the graphite from the anode and the cathode and of the treated graphite (control).

Microorganisms were observed in the anodic and cathodic graphite (Figure S1b, S1c). Although the cathodic and anodic microorganisms were attached to the graphite, the images suggested that there were morphological differences between the two chambers. The anodic microorganisms appeared dispersed and were rod-shaped. In contrast, the cathodic microorganisms appeared to aggregate in communities. The cathodic biofilm was more 
abundant than the anodic biofilm. However, the presence of bacterial pilli, was observed in both biofilms. Finally, precipitates were observed in the cathodic graphite.

3.5 The nitrate reduction mechanism and potential electron donors in the biocathode

Nitrate reduction to dinitrogen gas occurs through four sequential reduction reactions. ${ }^{8,9}$ During these reactions, two stable intermediates are potentially accumulated $\left(\mathrm{NO}_{2}{ }^{-}\right.$and $\left.\mathrm{N}_{2} \mathrm{O}\right) .{ }^{16}$ In this study, nitrate removal reduction differed during different periods. Initially, up to $43 \%$ of the reduced nitrate accumulated as $\mathrm{NO}_{2}{ }^{-}(31-45 \mathrm{~d})$, which indicated that less nitrite was reduced to nitrous oxide than nitrate was reduced to nitrite. This result indicates that different bacteria were catalysing nitrate reduction and nitrite reduction. Next, nitrite reduction improved and nitrite was almost completely removed $\left(0.14 \pm 0.13 \mathrm{mg} \mathrm{N}-\mathrm{NO}_{2}{ }^{-} \mathrm{L}^{-1}\right.$

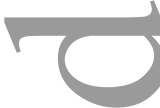
at the effluent on period 84-97d). However, high nitrous oxide accumulations ( $60 \%$ of nitrate removed on period 84-97d) were determined by the electron balance, coulombic efficiency at the cathode and Tafel plot analysis data. Thus, different microorganisms were catalysing nitrite reduction and nitrous oxide reduction. Consequently, it was demonstrated that nitrate is reduced to dinitrogen gas through sequential reduction reactions that involve nitrite and nitrous oxide in the MFC biocathode. Moreover, these reactions were catalysed by different bacteria. Thus, the entire denitrifying community is needed to reduce $\mathrm{NO}_{3}{ }^{-}$to $\mathrm{N}_{2}$ in a biocathode. The denitrifying community was able to acclimate in restricted conditions, such as low groundwater conductivity. In addition, because turbidity analyses showed no loss of biomass, the denitrifying community was able to remain inside the cathode as a biofilm (Table 3). The evolution of nitrate and nitrite reduction was observed during the entire study. When these results were combined with current production and electrochemical data from polarization curves, it was deduced that the activities of the denitrifying microorganisms were directly correlated with the electrical performance of the MFC. Thus, the nitrates and nitrites were mainly reduced by electrotroph bacteria. Nevertheless, not enough information was 
obtained to determine if the microorganisms can accept electrons directly from the electrode (direct electron transfer (DET)), the mechanism used is a mediated electron transfer (MET) or a combination of both, DET and MET, depending on the microorganism and the reaction. ${ }^{22} \mathrm{~A}$ combination of mediated and direct electron transfer would be reasonable due to the different steps that are involved in nitrate reduction to dinitrogen gas. This sequence of reactions makes also complex to calculate the theoretical cathodic potential for $\mathrm{NO}_{3}{ }^{-} / \mathrm{N}_{2}{ }^{13}$

The electrochemical data indicated that nitrate reduction by electroactive bacteria occurred, but other denitrifying bacteria could be active inside the biocathode. Conventional denitrification treatment relies on heterotrophic bacteria to reduce nitrates. In this study, no organic matter was added directly to the cathode influent. Moreover, TOC analysis from the influent and effluent identified values that were below the detection $\operatorname{limit}\left(<0.01 \mathrm{mgC} \mathrm{L}^{-1}\right)$ (Table 3). This finding removes the possibility of nitrate reduction by heterotrophic bacteria. However, this hypothesis cannot be completely discarded because Nafion ${ }^{\circledR}$ membranes (the membrane used in this study) allow some acetate diffusion (diffusion coefficient of $0.8210^{-9}$ $\left.\mathrm{cm}^{2} \mathrm{~s}^{-1}\right) .{ }^{23}$ However, the diffusion coefficient for acetate is very low and could only explain a small percent of the nitrate removed at the cathode. Thus, the majority of denitrification must occur by autotrophic denitrification. Some authors have described the use of hydrogen gas $\left(\mathrm{H}_{2}\right)$ as electron donor for autotrophic denitrification. ${ }^{24}$ Hydrogen gas can be delivered to bacteria by adding $\mathrm{H}_{2}$ directly to the reactor ${ }^{25}$ or by producing $\mathrm{H}_{2}$ in the reactor. ${ }^{26}$ However, no hydrogen gas was fed to the reactor. Moreover, to produce hydrogen in a bioelectrochemical system, a cathodic potential of at least $-410 \mathrm{mV} v s$. SHE is required. ${ }^{27}$ This potential can only be reached by applying an external voltage (Microbial Electrolysis Cell (MEC)). Because no external voltage was applied in our study and the cathodic potential was always greater than $-200 \mathrm{mV} v s$. SHE, nitrate reduction with hydrogen as the electron donor was not considered. 
Sulphide $\left(\mathrm{S}^{2-}\right)$ is another electron donor that must be considered due to its possible presence in groundwater. Some authors have described sulphide as an electron donor for nitrate denitrification. ${ }^{28}$ During nitrate reduction, sulphide is oxidised to sulphate $\left(\mathrm{SO}_{4}{ }^{2-}\right)$.

Sulphate concentrations at the cathode influent and the effluent were monitored throughout the study, and no variations in sulphate concentration were observed during its transition through the cathode (Table 3). Thus, nitrate reduction coupled with sulphide as an electron donor was not considered.

\subsection{Bioelectrochemical approach perspective for groundwater bioremediation}

The groundwater used in that study met drinking water quality standards for $\mathrm{pH}$, conductivity, sulphates, chlorides, ammonium, organic matter (TOC) and turbidity. These parameters were monitored during the study to determine if they changed. Table 3 contains the mean $\mathrm{pH}$, conductivity, sulphate, chloride, organic matter (TOC) and turbidity in the cathodic chamber influent and effluent during the entire study. Except for the nitrogen compounds, which were affected by the bioremediation process in the cathode, the quality of the studied parameters was not affected. Sulphate concentrations did not change between influent and effluent, which suggested that no nitrate reduction by sulphur oxidation occurred. Ammonium was not detected in the influent or the effluent, whichindicated that nitrate was not reduced to ammonium. Special attention must be given to organic matter content (TOC), which was always below the detection limit. These results indicated that no variations in total organic carbon concentrations were produced during the bioremediation process. However, acetate could diffuse from the anode to the cathode through the cation exchange membrane. The membrane used in this study has an acetate diffusion coefficient of $0.8210^{-9} \mathrm{~cm}^{2} \mathrm{~s}^{-1},{ }^{23}$ which would account for a very low nitrate removal by heterotrophic bacteria. Nevertheless, from the TOC analyses, it was hypothesised that all potentially diffused acetate was consumed by denitrifying bacteria. 


\section{CONCLUSIONS}

Nitrate-contaminated groundwater can be successfully treated by using a microbial fuel cell, despite the low conductivity $\left(955 \pm 121 \mu \mathrm{S} \mathrm{cm}^{-1}\right)$ of this water. Groundwater was treated in a biocathode, which resulted in a nitrate concentration decrease from $28.32 \pm 6.15$ to $12.14 \pm$ $3.59 \mathrm{mg} \mathrm{N}-\mathrm{NO}_{3}{ }^{-} \mathrm{L}^{-1}$ with no nitrite accumulation $\left(0.14 \pm 0.13 \mathrm{mg} \mathrm{N}-\mathrm{NO}_{2}^{-} \mathrm{L}^{-1}\right.$ at the effluent). However, coulumbic efficiencies, polarization curves and the nitrogen electron balance at the cathode suggested that nitrous oxide accumulation occurred. The Tafel plot analysis indicated that different rate-determining step reactions occurred during the entire study as nitrate reduction evolved through its sequential steps from $\mathrm{NO}_{3}{ }^{-}$to $\mathrm{N}_{2}$. The bioremediation process did not affect the drinking water quality based on the studied parameters.

\section{ACKNOWLEDGMENTS}

This research was financially supported by the Spanish Government (CONSOLIDER CSD2007-00055, CTQ 2011-23632, IPT-2011-1073-310000). N.P. was supported by a project grant from the Catalan Government (2012 FI-B 00941). The authors acknowledge the assistance of Carme Carulla (Serveis Tècnics de Recerca of the University of Girona).

\section{REFERENCES}

1 Menció A; Boya M; Mas-Pla J, Analysis of vulnerability factors that control nitrate occurrence in natural springs (Osona Region, NE Spain). Sci. Total Environ. 409 (16), 3049-3058 (2011). 
$2 \mathrm{Qu}$ J; Fan M, The current state of water quality and technology development for water pollution in China. Crit. Rev. Env. Sci. Tec. 40 (6), 519-560 (2010).

3 Safe Drinking Water Act (SDWA); P.L. 93-523.

4 Nitrates Directive; 91/767/EU.

5 Water Framework Directive (WFD); 2000/60/EC.

6 Groundwater Directive (GWD); 2006/118/EC.

7 EPA, Environmental Protection Agency. Consumer Factsheet on Nitrates/Nitrites. (2006)

8 Shrimali, M; Singh KP, New methods of nitrate removal from water. Environ. Pollut. 112 (3), 351-359 (2001).

9 Clauwaert P; Rabaey K; Aelterman P; De Schamphelaire L; Pham TH; Boeckx P; Boon N; Verstraete W, Biological denitrification in microbial fuel cells. Environ. Sci. Technol. 41 (9), 3354-3360 (2007).

10 Virdis B; Rabaey K; Yuan Z; Keller J, Microbial fuel cells for simultaneous carbon and nitrogen removal. Water Res. 42 (12), 3013-3024 (2008).

11 Puig S; Serra M; Vilar-Sanz A; Cabré M; Bañeras LL; Colprim J; Balaguer MD, Autotrophic nitrite removal in the cathode of microbial fuel cells. Bioresour. Technol. 102 (6), 4462-4467 (2011).

12 Desloover J; Puig S; Virdis B; Clauwaert P; Boeckx P; Verstraete W; Boon N, Biocathodic nitrous oxide removal in bioelectrochemical systems. Environ. Sci. Technol. 45 (24), 10557-10566 (2011).

13 Puig S; Coma M; Desloover J; Boon N; Colprim J; Balaguer MD, Autotrophic denitrification in microbial fuel cells treating low ionic strength water. Environ. Sci. Technol. 46 (4), 2309-2315 (2012). 
14 Real Decreto 140/2003. Criterios sanitarios de la calidad del agua de consumo humano.

15 APHA. Standard Methods for the Examination of Water and Wastewater, $19^{\text {th }}$ ed. American Public Health Association, Washington, DC, USA. 2005.

16 Virdis B; Rabaey K; Yuan Z; Rozendal RA; Keller J, Electron fluxes in a Microbial Fuel Cell performing carbon and nitrogen removal. Environ. Sci. Technol. 43 (13), 5144-5149 (2009).

17 Rieger PH, Electrochemistry: second edition. ISBN 0-412-04391-2, ed by Chapman and Hall, Inc. USA (1994).

18 Bagotzky VS, Fundamentals of electrochemistry. ISBN 0-306-44338-4, ed by Plenum Press, New York (1993).

19 World Health Organization (WHO). Nitrate and nitrite in drinking-water: Background document for development of WHO Guidelines for drinking-water quality (2007).

20 Logan B; Hamelers B; Rozendal R; Schröder U; Keller J; Freguia S; Aelterman P; Verstraete W; Rabaey K, Microbial fuel cells: Methodology and technology. Environ. Sci. Technol. 40 (17), 5181-5192 (2006).

21 Venkata Mohan S; Srikanth S, Enhanched wastewater treatment efficiency through microbially catalyzed oxidation and reduction: Synergistic effect of biocathode microenvironment. Bioresour. Technol. 102 (22), 10210-10220 (2011).

22 Rosenbaum M; Aulenta F; Villano M; Angenent LT, Cathodes as electron donors for microbial methabolism: Which extracellular electron transfer mechanisms are involved? Bioresour. Technol. 102 (1), 324-333 (2011).

23 Kim JR; Cheng S; Oh S; Logan BE, Power generation using different cation, anion and ultrafiltration membranes in microbial fuel cells. Environ. Sci. Technol. 41 (3) 1004-1009 (2007) 
24 Karanasios KA; Vasiliadou, IA; Pavlou S; Vayenas DV, Hydrogenotrophic denitrification of potable water: A review. J. Hazard. Mater. 189 (1-3), 20-37 (2010).

25 Park IH; Choi Y; Pak D, Autohydrogenotrophic denitrifying microbial community in a glass beads biofilm reactor. Biotechnol. lett. 27 (13), 949-953 (2005).

26 Wan D; Liu H; Qu J; Lei P, Bio-electrochemical denitrification by a novel protonexchange membrane electrodialysis system - a batch mode study. J. Chem. Technol. Biotechnol. 85 (11) 1540-1546 (2010).

27 Liu H; Grot S; Logan BE, Electrochemically assisted microbial production of hydrogen from acetate. Environ. Sci. Technol. 39 (11) 4317-4320 (2005).

28 Wan D; Liu H; Qu J; Lei P; Xiao S; Hou Y, Using the combined bioelectrochemical and sulphur autotrophic denitrification system for groundwater denitrification. Biores.

Technol. 100 (1) 142-148 (2009). 


\section{FIGURE CAPTIONS}

Figure 1. Evolution of nitrogen compounds transformations during the study period. Error bars represent the standard deviations of the replicate samples $(n \geq 4)$.

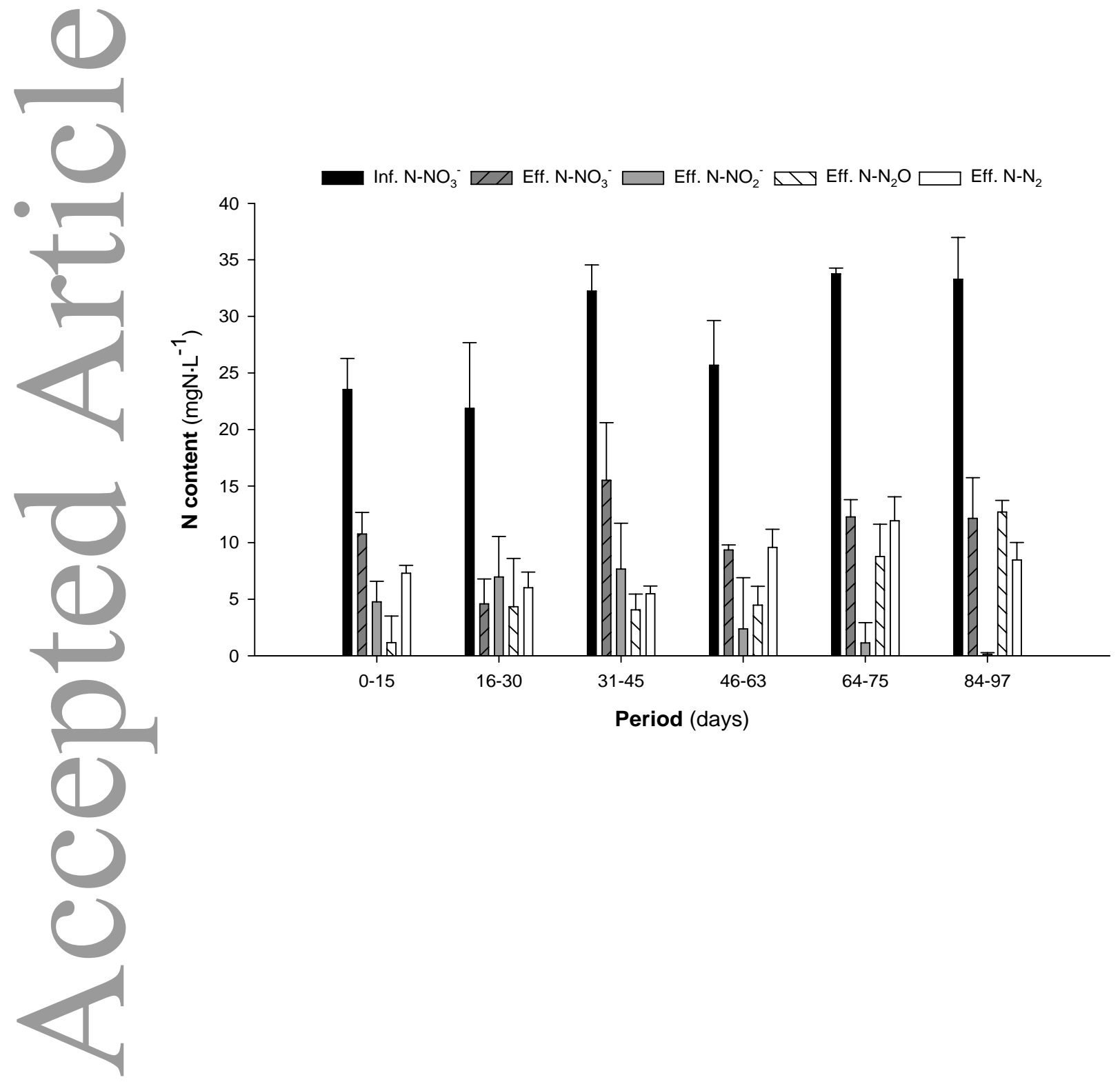


Figure 2. Tafel slope analyses generated at the biocathode for different days of the study.

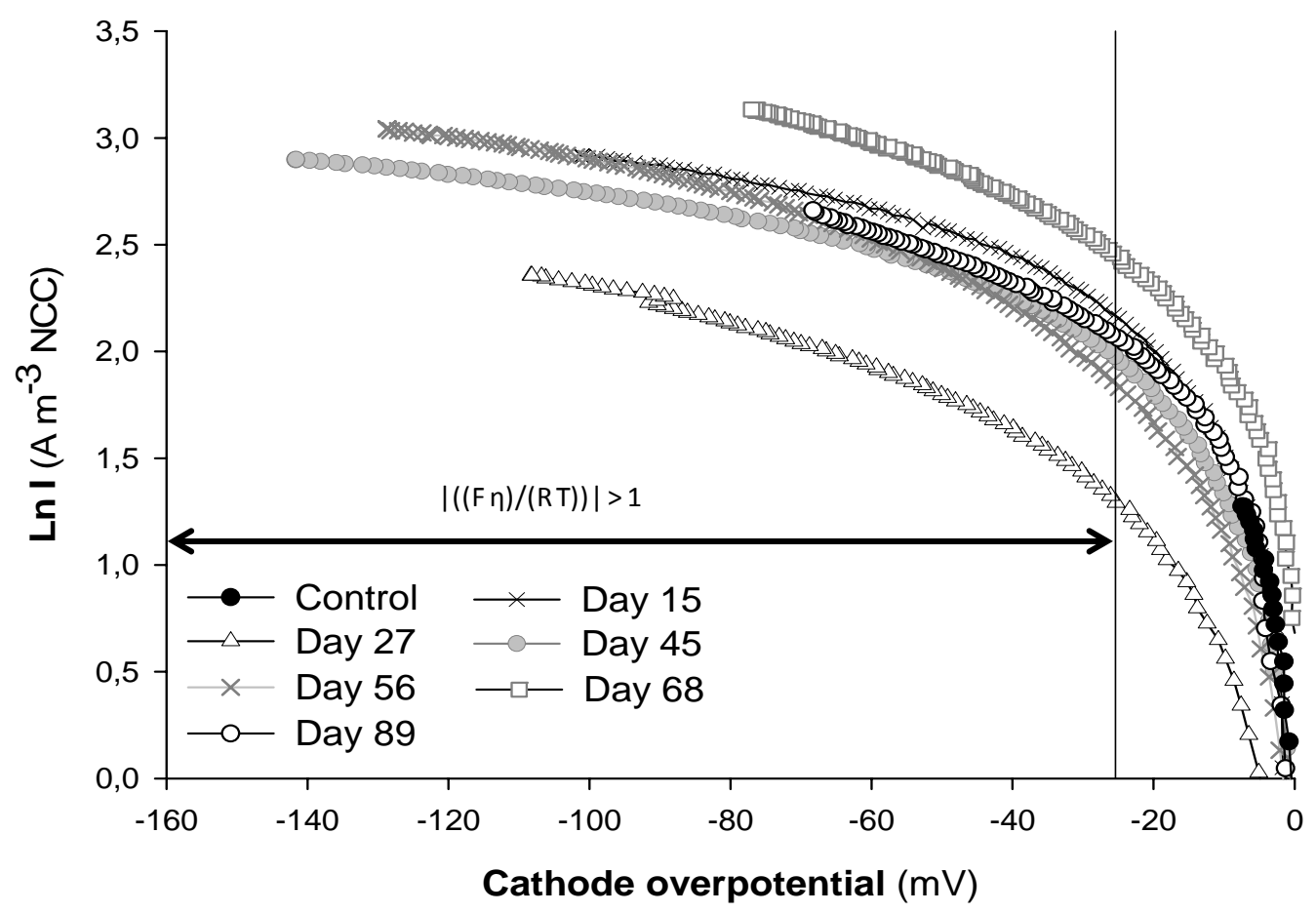




\section{LIST OF TABLES}

Table 1. Characteristics of groundwater treated in the MFC cathode during the experimental study. The results are presented as the mean \pm standard deviation of replicate samples $(n \geq 4)$.

\begin{tabular}{|c|c|c|c|c|c|c|c|}
\hline $\begin{array}{l}\text { Period } \\
\text { (days) }\end{array}$ & $\begin{array}{l}\text { Conductivity } \\
\left(\mu \mathrm{S} \mathrm{cm}^{-1}\right)\end{array}$ & pH & $\begin{array}{c}\mathbf{N}-\mathbf{N O}_{3}^{-} \\
\left(\mathrm{mg} \mathrm{N} \mathrm{L}^{-1}\right)\end{array}$ & $\begin{array}{c}\mathbf{N}^{-N_{2}}{ }_{2}^{-} \\
\left(\mathrm{mg} \mathrm{N} \mathrm{L}^{-1}\right)\end{array}$ & 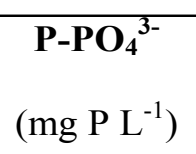 & $\begin{array}{c}\mathbf{S - S O}_{4}{ }^{2-} \\
\left(\mathrm{mg} \mathrm{S} \mathrm{L}^{-1}\right)\end{array}$ & $\begin{array}{c}\mathrm{Cl}^{-} \\
\left(\mathrm{mg} \mathrm{Cl} \mathrm{L}^{-1}\right)\end{array}$ \\
\hline $0-15$ & & & $23.53 \pm 2.74$ & $0.44 \pm 0.77$ & $0.24 \pm 0.48$ & $18.19 \pm 1.68$ & $49.63 \pm 14.32$ \\
\hline $16-30$ & $700 \pm 121$ & $8.0 \pm 0.2$ & $21.88 \pm 5.80$ & $0.01 \pm 0.01$ & $0.70 \pm 1.03$ & $17.52 \pm 1.16$ & $38.85 \pm 7.06$ \\
\hline $31-45$ & $952 \pm 121$ & $8.0 \pm 0.1$ & $32.23 \pm 2.32$ & $0.46 \pm 0.50$ & $1.72 \pm 0.88$ & $18.74 \pm 0.97$ & $49.54 \pm 9.32$ \\
\hline $46-63$ & $883 \pm 121$ & $8.0 \pm 0.2$ & $25.69 \pm 3.95$ & $0.10 \pm 0.10$ & $0.58 \pm 0.53$ & $12.31 \pm 6.81$ & $34.79 \pm 9.59$ \\
\hline $64-75$ & $1055 \pm 59$ & $8.0 \pm 0.1$ & $33.77 \pm 0.51$ & $0.32 \pm 0.32$ & $1.26 \pm 0.78$ & $18.80 \pm 1.27$ & $46.09 \pm 1.75$ \\
\hline $84-97$ & $855 \pm 66$ & $8.1 \pm 0.1$ & $33.29 \pm 3.70$ & $0.16 \pm 0.33$ & $0.21 \pm 0.16$ & $19.31 \pm 1.34$ & $48.71 \pm 4.93$ \\
\hline Average & $955 \pm 121$ & $8.0 \pm 0.2$ & $28.32 \pm 6.15$ & $0.24 \pm 0.40$ & $0.65 \pm 0.73$ & $17.48 \pm 3.72$ & $43.67 \pm 10.25$ \\
\hline
\end{tabular}


Table 2. Tafel plot analysis results for the anode and cathode during the entire study.

Legend: n.a. $=$ not applicable.

\begin{tabular}{|c|c|c|c|c|c|c|c|c|c|c|c|c|}
\hline Day & \multicolumn{2}{|c|}{15} & \multicolumn{2}{|c|}{27} & \multicolumn{2}{|c|}{45} & \multicolumn{2}{|c|}{56} & \multicolumn{2}{|c|}{68} & \multicolumn{2}{|c|}{89} \\
\hline Compartment & $\begin{array}{c}\text { An } \\
\text { od } \\
\text { e }\end{array}$ & $\begin{array}{c}\text { Cat } \\
\text { hod } \\
\text { e }\end{array}$ & $\begin{array}{c}\text { An } \\
\text { od } \\
\text { e }\end{array}$ & $\begin{array}{c}\text { Cat } \\
\text { hod } \\
\text { e }\end{array}$ & $\begin{array}{c}\text { An } \\
\text { od } \\
\text { e }\end{array}$ & $\begin{array}{c}\text { Cat } \\
\text { hod } \\
\text { e }\end{array}$ & $\begin{array}{c}\text { An } \\
\text { od } \\
\text { e }\end{array}$ & $\begin{array}{c}\text { Cat } \\
\text { hod } \\
\text { e }\end{array}$ & $\begin{array}{c}\text { An } \\
\text { od } \\
\text { e }\end{array}$ & $\begin{array}{c}\text { Cat } \\
\text { hod } \\
\text { e }\end{array}$ & $\begin{array}{c}\text { An } \\
\text { od } \\
\text { e }\end{array}$ & $\begin{array}{c}\text { Cat } \\
\text { hod } \\
\text { e }\end{array}$ \\
\hline $\begin{array}{cc}\text { Elect } & \alpha \\
\text { ron } & \text { (Redu } \\
\text { trans } & \text { ctive) }\end{array}$ & n.a. & 0.23 & n.a. & 0.31 & n.a & 0.18 & n.a. & 0.27 & n.a. & 0.32 & n.a. & 0.33 \\
\hline \begin{tabular}{cc}
\cline { 2 - 2 } coeffi & $\beta(O x i$ \\
cient & dative \\
& )
\end{tabular} & $\begin{array}{c}0.2 \\
8\end{array}$ & n.a. & $\begin{array}{c}0.2 \\
4\end{array}$ & n.a. & $\begin{array}{c}0.3 \\
8\end{array}$ & n.a. & $\begin{array}{c}0.2 \\
5\end{array}$ & n.a. & $\begin{array}{c}0.1 \\
9\end{array}$ & n.a. & $\begin{array}{c}0.1 \\
7\end{array}$ & n.a. \\
\hline $\begin{array}{c}\mathbf{i}_{\mathbf{0}} \\
\left(\mathrm{A} \mathrm{m}^{-3}\right)\end{array}$ & $\begin{array}{c}7.3 \\
9\end{array}$ & 8.00 & $\begin{array}{c}5.6 \\
0\end{array}$ & 3.15 & $\begin{array}{c}5.2 \\
5\end{array}$ & 7.30 & $\begin{array}{c}7.3 \\
3\end{array}$ & 6.16 & $\begin{array}{c}8.0 \\
3\end{array}$ & 9.11 & $\begin{array}{c}8.7 \\
3\end{array}$ & 5.98 \\
\hline $\begin{array}{c}\mathbf{E}^{\mathbf{0}} \\
(\mathrm{mV} \text { vs. SHE) }\end{array}$ & $\begin{array}{c}- \\
29 \\
7\end{array}$ & -51 & $\begin{array}{c}- \\
36 \\
4\end{array}$ & -122 & $\begin{array}{c}- \\
31 \\
3\end{array}$ & -43 & $\begin{array}{c}- \\
27 \\
2\end{array}$ & 42 & $\begin{array}{c}- \\
31 \\
4\end{array}$ & 14 & $\begin{array}{c}- \\
23 \\
1\end{array}$ & 53 \\
\hline
\end{tabular}


Table 3. Cathodic influent and effluent characteristics during the study and the limits given by the Spanish legislation for drinking water. ${ }^{14}$ The results are presented as the mean \pm standard deviation of replicates samples

\begin{tabular}{|c|c|c|c|c|c|c|}
\hline & $\begin{array}{l}\text { Conductivity } \\
\left(\mu \mathrm{Sm}^{-1}\right)\end{array}$ & $\mathrm{pH}$ & 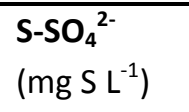 & $\begin{array}{l}\mathrm{Cl}^{-} \\
\left(\mathrm{mg} \mathrm{Cl} \mathrm{L}^{-1}\right)\end{array}$ & $\begin{array}{l}\text { Turbidity } \\
\text { (NTU) }\end{array}$ & $\begin{array}{l}\text { TOC } \\
\text { (mg C L-1) }\end{array}$ \\
\hline Influent & $955 \pm 121$ & $8.0 \pm 0.2$ & $17.48 \pm 3.72$ & $43.67 \pm 10.25$ & $1.01 \pm 0.11$ & $<0.01$ \\
\hline Effluent & $988 \pm 113$ & $8.7 \pm 0.3$ & $17.84 \pm 3.83$ & $41.83 \pm 7.77$ & $0.5 \pm 0.1$ & $<0.01$ \\
\hline $\begin{array}{l}\text { Limit given by } \\
\text { Spanish } \\
\text { legislation }{ }^{14}\end{array}$ & $<2500$ & $\begin{array}{l}6.5<x \\
<9.5\end{array}$ & $<83.33$ & $<250$ & $\leq 1$ & $\begin{array}{l}\text { Without } \\
\text { significant } \\
\text { changes }\end{array}$ \\
\hline
\end{tabular}

